\title{
Flank stability and processes off the western Canary Islands: a review from El Hierro and La Palma*
}

\author{
R. URGELES ${ }^{1}$, M. CANALS ${ }^{1}$ and D.G. MASSON ${ }^{2}$ \\ ${ }^{1}$ GRC Geociències Marines, Universitat de Barcelona, Dept. d'Estratigrafia i Paleontologia, Campus de Pedralbes, \\ E-08028 Barcelona, Spain. \\ ${ }^{2}$ Southampton Oceanography Centre, Challenger Division for Seafloor Processes, Empress Dock, \\ Southampton SO14 3ZH, United Kingdom.
}

\begin{abstract}
SUMMARY: The morphological characterisation of the western submarine island flanks of El Hierro and La Palma differentiates four type-zones that may give new insights into the evolution of oceanic island slopes. The different type-zones result from the interplay between constructive volcanic processes, hemipelagic settling and volcano collapses. The latter results in massive debris avalanche deposits, which form large volcaniclastic aprons. In most cases, the headwall scarps are clearly exposed on the emerged part of the islands. The events that occurred in the youngest and westernmost islands of El Hierro and La Palma have vertical runouts exceeding 6,000 $\mathrm{m}$ and volumes that can reach several hundred $\mathrm{km}^{3}$. The landslide frequency for the entire Canaries is one major event per $90 \mathrm{ka}$. Triggering mechanisms are closely related to magmatic processes. The increase in the shear stress is directly linked with the forceful intrusion of magma along "ridge-rift" systems, while in the western Canary Islands it seems that the main process reducing shear resistance may be related to the rise in pore pressure due to hydrothermal circulation.
\end{abstract}

Key words: landslides, debris avalanches, Canary Islands, El Hierro, La Palma.

\section{INTRODUCTION}

Several debris avalanches involving large volumes of volcaniclastic material have recently been discovered on the submarine slopes of the Canary Islands (Watts and Masson, 1995, 1998; Masson, 1996; Urgeles et al., 1997, 1999b; Funck and Schminke, 1998) (Fig. 1). Relatively old buried debris avalanches have been described off Gran Canaria by Funck and Schminke (1998), while the largest debris avalanche complex has been found off north Tenerife covering an area of $5,500 \mathrm{~km}^{2}$ with an estimated volume of about $1,000 \mathrm{~km}^{3}$ (Watts and Masson, 1995). Three large debris

\footnotetext{
*Received January 17, 2000. Accepted July 20, 2000.
}

avalanches appear to have occurred on the island of El Hierro: El Golfo, on the northwest flank, El Julán, on the southwest flank, and Las Playas, on the southeast flank. El Golfo covers $2,600 \mathrm{~km}^{2}$ of the sea-floor and involves $180 \mathrm{~km}^{3}$ of mobilized debris (Urgeles et al., 1997), El Julán covers 900 $\mathrm{km}^{2}$ and is $100 \mathrm{~km}^{3}$ in volume (Holcomb and Searle, 1991). The western flank of La Palma is affected by up to four debris avalanches, giving an overall volume of $750 \mathrm{~km}^{3}$ (Urgeles et al., 1999b). Our own limited swath bathymetry data suggest that the northern and eastern flanks of La Palma are also probably affected by landslides that still remain undescribed. Hence, debris avalanche deposits seem to cover considerable portions of the seafloor surrounding the Canary Islands, as also occurs 
around the Hawaiian Archipelago, where half of the perimeter of the volcanic ridge is capped by such deposits (Moore et al., 1994).

In the Canaries, there are good examples of large amphitheatre-shaped scarps and internal discordances that, together with the so-called mortalon deposits (a sort of volcaniclastic, plastic breccia), have been related to the giant landslides (Fúster $e t$ al., 1993; Ancochea et al., 1994; Carracedo, 1994). Such structures have been known for a long time (Hausen, 1961, 1969, 1973; Ridley, 1971; Bravo, 1962, 1982; Navarro and Coello, 1989), but they were not clearly explained until Holcomb and Searle (1991) first related them to huge submarine debris avalanches on the island flanks.

This article reviews general features of the giant Canarian landslides, with special emphasis on the submarine flanks of the two westernmost Canary Islands, El Hierro and La Palma. The main features of the landslides observed in the two islands are described, with criteria for their identification. The article provides relevant information to estimate the significance of such processes in the overall evolution of the islands and the adjacent basin. Finally, the paper furnishes age constraints and suggests triggering mechanisms for individual landslides. The work is based on data from state-of-the-art submarine geophysical techniques, including Simrad
EM-12S multibeam bathymetry (Keeton and Searle, 1996), TOBI (Towed Ocean Bottom Instrument) deep-towed side-scan sonar (Flewellen et al., 1993), high- and ultrahigh-resolution seismic reflection profiles, and PUPPI (Pop Up Pore Pressure Instrument) pore pressure measurements (Schultheiss, 1989).

\section{THE GEOLOGICAL SETTING OF THE CANARY ISLANDS AND BASIN}

Including both the subaerial and submarine parts, the Canary Basin covers $3.36 \times 10^{6} \mathrm{~km}^{2}$. It is bounded by the eastern flank of the Mid-Atlantic Ridge to the west, by the Açores-Gibraltar rise to the north, by the Madeira-Tore rise to the northeast, by the Cabo Verde rise to the south, and by the Atlas mountain range to the east. The Canary Islands are located near the centre of the basin, whose deepest point $(5,300 \mathrm{~m}$ water depth) is located in the Madeira Abyssal Plain (MAP). The Canary Archipelago consists of seven major islands, roughly oriented E-W (Fig. 1). The most outstanding subaerial feature is the $3,700 \mathrm{~m}$ high Teide volcano, on the island of Tenerife, which is the third highest oceanic volcano on Earth after Mauna Kea and Mauna Loa in Hawaii.

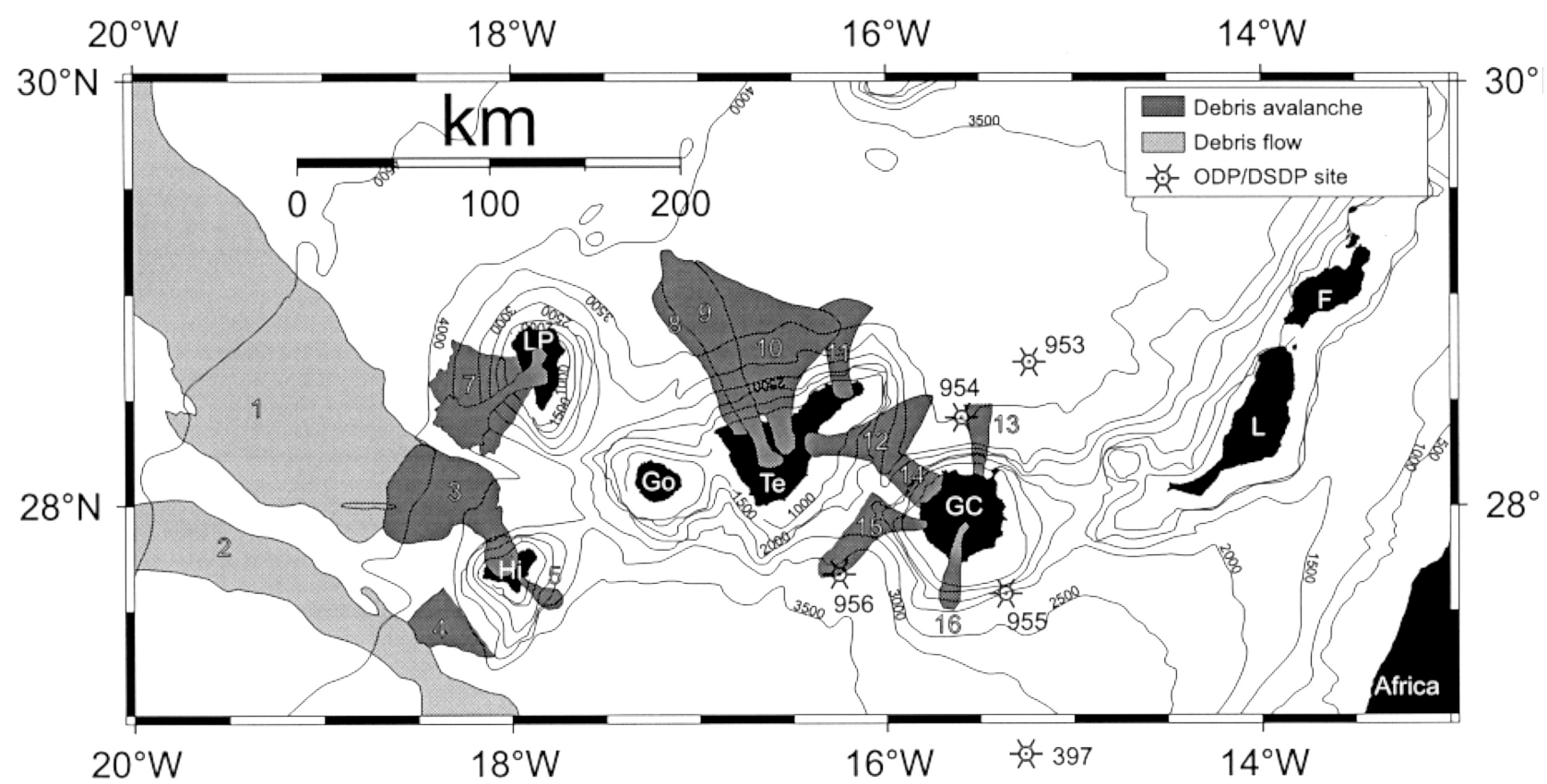

FIG. 1. - Giant landslides in the Canary Basin. 1) Canary debris flow (17-10 ka); 2) Saharan debris flow (15 ka); 3 ) El Golfo debris avalanche $(136-21 \mathrm{ka})$; 4) El Julán debris avalanche (160 ka); 5) Las Playas debris avalanche (250 ka); 6) Cumbre Nueva debris avalanche (536 - 135 ka); 7) Playa de la Veta debris avalanche complex (1 Ma $-0.8 \mathrm{Ma}) ; 8)$ Teno debris avalanche ( $>0.5 \mathrm{Ma})$; 9) Icod debris avalanche ( 0.17 Ma); 10) La Orotava debris avalanche (0.65-0.35 Ma); 11) Anaga debris avalanche ( $>0.5 \mathrm{Ma})$; 12) Güimar debris avalanche (0.69-? Ma); and Gran Canària debris avalanches, 13) 12-14 Ma; 14) $14 \mathrm{Ma}$; 15) > $14 \mathrm{Ma}$; 16) $3.5 \mathrm{Ma}$ (Data from several authors cited in the text body). Location of neighbouring ODP/DSDP drill sites is also shown. 
Results from the DSDP drill site 397, $100 \mathrm{~km}$ SSE of Gran Canaria, demonstrate that volcaniclastic flows entered the Canary Basin at about $17 \mathrm{Ma}$ BP. These flows would reflect the rapid growth of the island of Fuerteventura during the shield phase (von Rad et al., 1979; Schminke, 1990). North and south of Gran Canaria, the drilling of the island apron (ODP drill sites 953 to 956) showed that all the evolutionary phases of the island, both volcanic and non-volcanic, are present in the marine record (ODP Leg 157 Shipboard Scientific Party, 1995). The pattern of sediment influx observed west of the islands of El Hierro and La Palma indicates that the migrating volcanism controls the sedimentary processes and the location of volcaniclastic depocentres (Urgeles et al., 1998). In the MAP, a dense grid of seismic reflection profiles shows three main seismostratigraphic units. The lower unit is mainly made of pelagic sediments, whereas the intermediate and upper units are dominated by turbidites (Duin et al., 1984; Searle, 1987). ODP drill sites 950, 951 and 952 in the MAP show that the first volcaniclastic flows reached this western part of the Canary Basin only 6,5 Ma ago (ODP Leg 157 Shipboard Scientific Party, 1995), but older flows had already been reaching the areas of the basin west of El Hierro and La Palma since $17 \mathrm{Ma}$ (von Rad et al., 1979; Schminke, 1990).

The Canary Islands are built on the passive continental slope and rise of northwest Africa. The eastern islands of Lanzarote and Fuerteventura overlie a transitional crust, which at some time in the past was probably oceanic (Roeser et al., 1971), whereas the central and western islands of Gran Canaria, Tenerife, La Gomera, La Palma and El Hierro lie on oceanic crust (Rothe and Schminke, 1968). This crust is fractured by two main fault systems: a WNW-ESE oriented Atlantic system, and an ENEWSW to NNE-SSW oriented system related to the Atlas Range (Mezcúa et al., 1991).

It is generally accepted that the Canary Islands resulted from a mantle plume, as suggested by the westward decrease in the age of each individual island. This would indicate an eastward movement over a hot spot of the lithospheric plate supporting the islands. The age of the shield phase of the various islands ranges from 20.7 Ma for the easternmost island of Lanzarote (Schminke, 1990) to only 1.12 Ma for the westernmost island of El Hierro (Guillou et al., 1996). However, according to Watts (1994), the hot spot theory does not provide satisfactory explanations for (i) the absence of parallelism between the Canary Ridge and the absolute direction of migration of the African plate; (ii) the lack of an intraplate topographic swell, as exists in Hawaii; and (iii) the absence of a long wavelength gravity peak. Nevertheless, seismic reflection and gravity data presented by Ranero et al. (1995), Canales and Dañobeitia (1998) and Urgeles et al. (1998) reveal a moderate swell centred in the western islands.

Holik and Rabinowitz (1991) interpreted a seismic high velocity layer with chaotic facies between $31^{\circ} \mathrm{N}$ and $33^{\circ} \mathrm{N}$ as indicative of the hot spot trace between 50 and $60 \mathrm{Ma}$ ago. Their data suggest a progression of the Canary hot spot from the northeast to the southwest. Rhim et al. (1998) suggested that a group of seamounts, Las Hijas, located southwest of El Hierro Island might represent the propagation of the Canary volcanism following that direction. In contrast, Carracedo et al. (1998) suggests that the distribution of the volcanism associated with the Canary hot spot was initially controlled by sediment thickness, the position of the continental-oceanic crust boundary, and the slow movement of the African plate. According to these authors, the thick sedimentary sequence of the Northwest African margin would have been the most favourable initial location for the first Canarian volcanism, which would later have propagated northeast and southwest along the weak transitional zone, dividing the continental from the oceanic crust. Carracedo et al. (1998) postulate that following this initial phase, the hot spot started the slow westward migration to follow the general E-W trend of the islands.

\section{GEOLOGICAL BACKGROUND ONSHORE EL HIERRO AND LA PALMA}

El Hierro and La Palma, the westernmost Canary Islands, have a similar history of building of successive volcanic edifices and destruction by giant landslides (Fig. 2). On El Hierro three large volcanic edifices have been identified which appear dislocated by subsequent giant landslides (Carracedo et al., 1995; Guillou et al., 1996). Those are the volcanic edifices of El Tiñor (1.12-0.88 Ma), El Golfo (545$176 \mathrm{ka}$ ), and Frontera (37 ka - present).

In the same way as El Hierro, La Palma was formed by successive volcanic edifices, subsequently truncated by large lateral collapses (Ancochea $e t$ al., 1994). A distinctive geological feature of La Palma is its basal complex, constituted by submarine extrusive and plutonic rocks cut by several dyke 


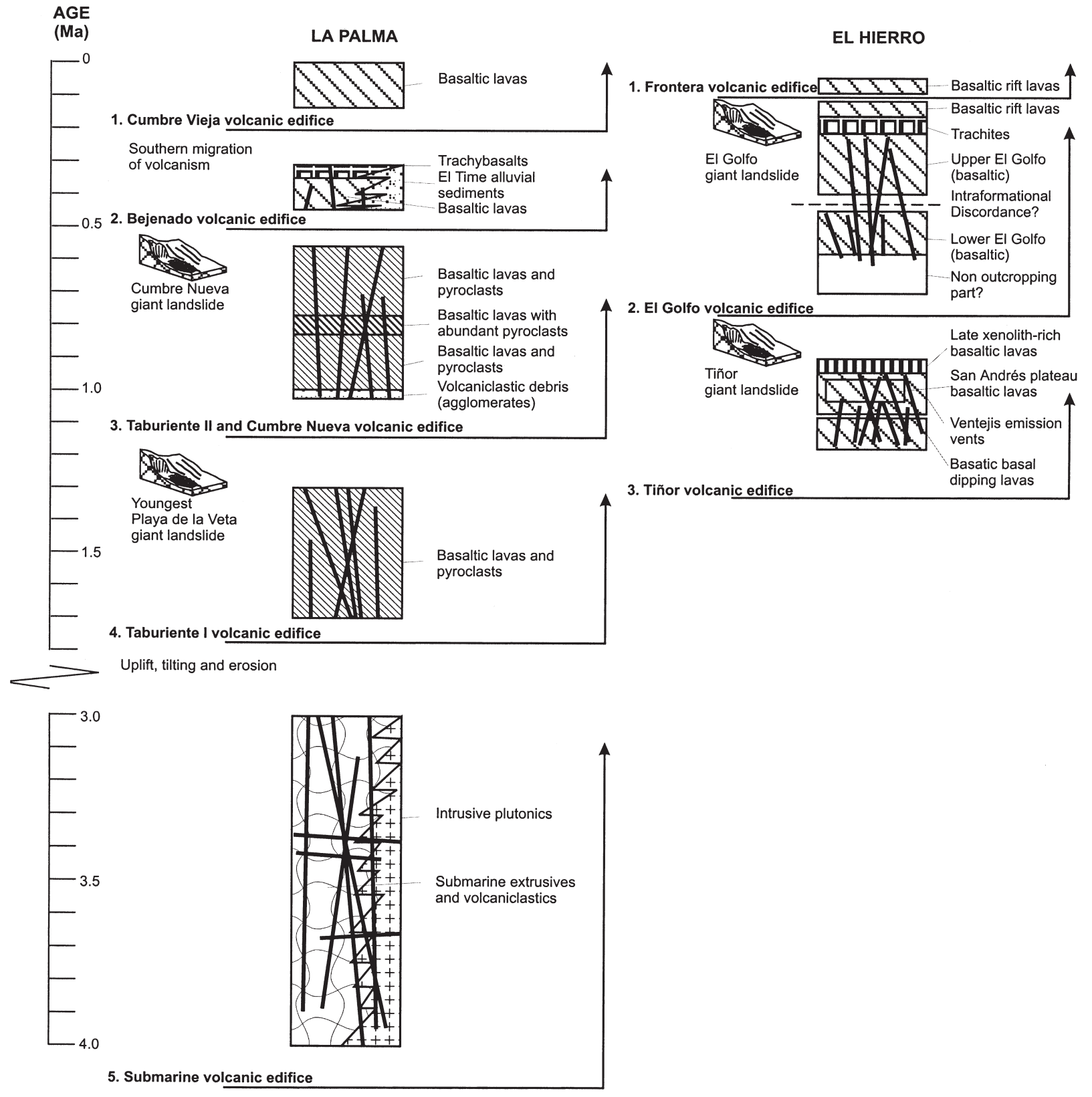

FIG. 2. - Sketches summarising the geological history of the islands of El Hierro and La Palma with major geological units and events (according to data from several authors cited in the body of the text, and in Navarro and Coello, 1993).

swarms, whose age is 4 to $3 \mathrm{Ma}$ (Gee et al., 1993). Above this, three subaerial volcanic edifices developed as in El Hierro. The oldest one is the Taburiente volcano, in the northern part of the island, which is divided into two piles by a conspicuous internal discordance, attributed to a major landslide followed by a period of magmatic quiescence (Ancochea et al., 1994). During the latest stage in the development of the Taburiente volcano, the activity shifted to the south forming the Cumbre Nueva Ridge (Carracedo et al., 1999). Together, the
Taburiente-Cumbre Nueva volcanic edifices were formed between 1.7 Ma and $560 \mathrm{ka}$ ago (Wijbrans et al., 1997; Carracedo et al., 1999). The TaburienteCumbre Nueva edifices finally collapsed, probably leading to the formation of the Bejenado volcano. After a new period of magmatic quiescence, volcanic activity shifted again to the south with the eruption of the most recent lavas, which constitute the Cumbre Vieja Ridge, the prominent southern ridge along which most of the historical volcanism is concentrated (Carracedo et al., 1999). 
SUBMARINE EVIDENCES OF LARGE SCALE MASS-WASTING IN THE CANARY ISLANDS OF EL HIERRO AND LA PALMA

\section{Geomorphology and acoustic character of the submarine-subaerial island flanks}

Combined swath bathymetry and onshore topographic data allow to distinguish four main physiographic type-zones on the flanks of El Hierro and La Palma (Fig. 3).

(1) The first type-zone stretches out west of $18^{\circ} 25^{\prime} \mathrm{W}$. The relief is smooth and lacks distinct highs. Mean slope gradients are less than $1^{\circ}$. North of $28^{\circ} 30^{\prime} \mathrm{N}$, NNE-SSW oriented lineations with a topographic expression of a few metres can be observed.

(2) The second type-zone extends south of the Cumbre Vieja Ridge, off the island of La Palma and south of El Hierro southern ridge. It shows average slope gradients of between $12^{\circ}$ and $14^{\circ}$, and rough topography with volcanic cones standing 300 to 400 $\mathrm{m}$ high above the surrounding sea-floor.

(3) The third type-zone lies seaward of El Hierro's north-eastern and western ridges, and offshore north of the Taburiente volcano, on La Palma. The

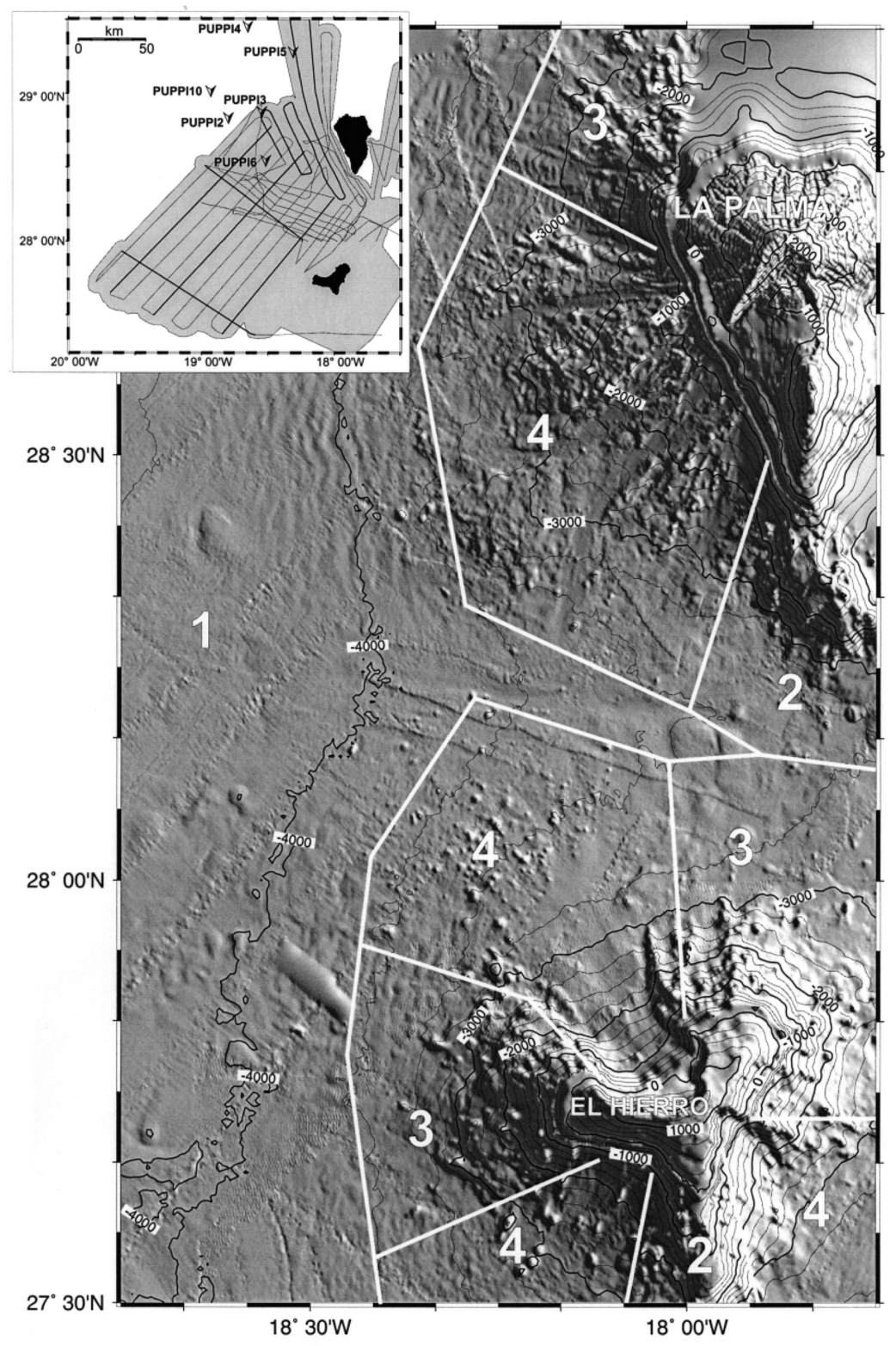

FIG. 3. - Bathymetry and topography of the islands of El Hierro and La Palma indicating the geomorphological type-zones division of their flanks. Upper left insert shows coverage of data used in this article. Arrows show PUPPI sites, bold lines show airgun seismic reflection profiles, thin lines are TOPAS parametric source and conventional $3.5 \mathrm{kHz}$ profiles, dashed area is swath bathymetry coverage. 


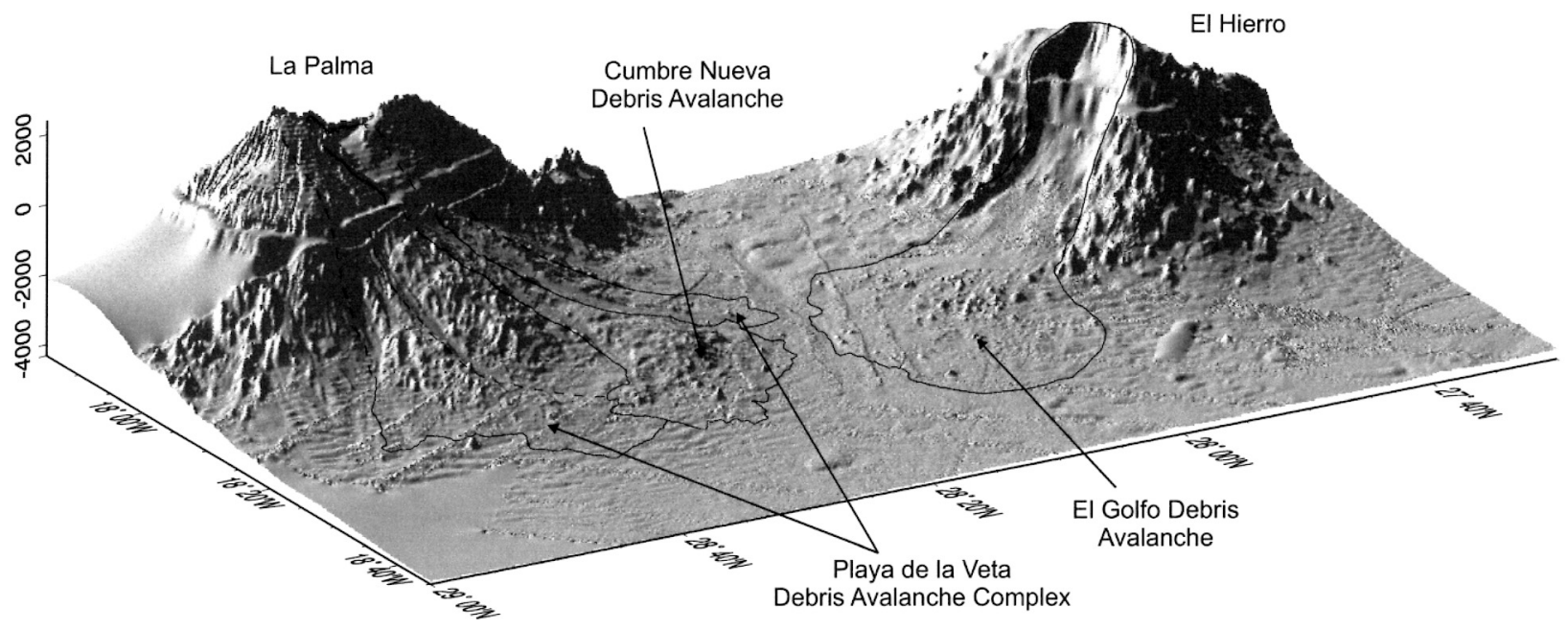

FIG. 4. - Three-dimensional view from the NW of the islands of El Hierro and La Palma, with indications of the landslide boundaries.

topography here is uneven and mean slopes are about $10^{\circ}$. A poorly-developed submarine sediment drainage system can be identified from swath bathymetry data (Urgeles et al., 1999b), as well as a set of volcanic cones $200-500 \mathrm{~m}$ high, some of which occur on well-defined NW-SE trends.

(4) The fourth type-zone is located seaward of the $14 \mathrm{~km}$ diameter El Golfo embayment, on El Hierro, and west of the Cumbre Nueva Arc and Caldera de Taburiente, on La Palma. Continuity in the submarine environment of the subaerial scarps surrounding El Golfo has been clearly demonstrated on the island of El Hierro (Urgeles et al., 1997). However, on La Palma, the offshore continuity of the subaerial scarps of the Caldera de Taburiente and Cumbre Nueva Arc is less evident (Urgeles et al., 1999b) (Fig. 4). In both cases, it has been shown that the subaerial or submarine escarpments, evolve into large aprons extending seaward to about $70 \mathrm{~km}$ from the islands. The relief is in general smoother than in type-zones two and three, with mean slopes ranging between $4^{\circ}$ and $5^{\circ}$. On La Palma, this type-zone includes a well-developed drainage network, which consists of flat-bottom channels up to $2.5 \mathrm{~km}$ wide. On the distalmost sectors off El Hierro and La Palma, numerous hummocks up to $300 \mathrm{~m}$ high and 2 to $2.5 \mathrm{~km}$ in diameter are present, showing noteworthy similarities to those described on the base of other volcanic islands, such as Hawaii and La Reunion (Moore et al., 1995; Lenat et al., 1989).

The EM-12S backscatter strength is usually low within type-zone one, although subtle lineations can be seen, and it is high where volcanic rocks outcrop (type-zones two and three) and also in the channels occurring within zone four. Backscatter also shows a speckled pattern in the most distal sectors of typezone four. The higher resolution of TOBI data clears up the features observed on the EM-12S data. Hence, the hummocks within type-zone four corresponding to the speckled pattern observed on the backscatter data actually correspond to large volcanic blocks capped to different degrees by pelagic sediments (Masson, 1996; Urgeles et al., 1999b). Airgun seismic reflection profiles allow the subsurface geology to be explored down to the acoustic basement in some sectors. The records show a stratified sequence over most of the study area, with the exception of the large aprons in type-zone four, where seismic facies are transparent or hyperbolic (Urgeles et al., 1997, 1999b).

\section{Hints on mass-wasting processes}

From the different features observed in the geomorphological-geophysical data, the different processes acting on each type-zone can be deduced. Type-zone one is dominated by hemipelagic deposition. The southern continuation of the young Cumbre Vieja Ridge, type-zone two, seems to result mostly from volcanic eruptive processes. Morphological and age differences between type-zones two and three seem to indicate that the latter results from the interplay between submarine volcanic constructive processes and small-scale mass-wasting processes (Urgeles et al., 1999b), although similar reliefs have been interpreted to have been formed in 
subaerial conditions, later being drowned by subsidence (see Watts and Masson, 1995). Thus, La Palma provides a good example to understand the evolution of ocean island submarine slopes.

The most striking features of the western submarine flanks of La Palma and El Hierro appear within type-zone four. The large aprons spotted with huge volcanic blocks (Fig. 4), together with the acoustic characteristics observed in seismic reflection profiles, all seem to indicate that large-scale instability events in the form of debris avalanches are the source of such features. As observed on airgun seismic reflection profiles, the surface hyperbolae and chaotic or transparent internal structure of these aprons supports the idea that their internal structure is largely chaotic.

In addition to the large lateral collapses on the islands' flanks, which take the form of debris avalanches, the TOPAS and $3.5 \mathrm{kHz}$ high resolution profiles and the TOBI data indicate that large landslides also occur on the continental rise at the foot of the islands. These deposits are shown as transparent masses or as segments of opaque response on the high-resolution profiler records. TOBI sonographs show more or less convoluted lineations, which may correspond to flow lines within the landslide mass, and/or to sets of scarps in the headwall area (Masson et al., 1998). The deposits that originated from these landslides are interpreted to be debris flows. They lack a single, well-defined headwall scarp, which is here substituted by several sets of small scarps extending over broad areas. The debris flows only involve the first tens of metres of the fine-grain sediment cover but can achieve volumes even larger than those of debris avalanches (Masson et al., 1992).

\section{Significance of mass-wasting events on the flanks of El Hierro and La Palma}

Large debris avalanches and debris flows in the Canary Basin are catastrophic events. The debris avalanches were initiated at $1,500 \mathrm{~m}$ above sea level (asl) and 2,400 m asl on El Hierro and La Palma respectively (top of the headwall scarps), and the resulting submarine deposits are found at 4,100 m depth. This means that vertical runouts may reach $7,000 \mathrm{~m}$. The headwall scarps themselves may exceed $1,000 \mathrm{~m}$, and the resulting deposits may reach $500 \mathrm{~m}$ in thickness, with massive volcanic blocks up to $300 \mathrm{~m}$ in height and $2 \mathrm{~km}$ in diameter. The volumes involved in such processes are also extraordinary: $95 \mathrm{~km}^{3}$ in the Cumbre Nueva debris avalanche on La Palma; $150-180 \mathrm{~km}^{3}$ in the El Golfo debris avalanche on El Hierro; and $650 \mathrm{~km}^{3}$ in the Playa de la Veta debris avalanche complex, again in La Palma (Urgeles et al., 1997, 1999b). The volumes involved in the landslides represent significant parts of the total submarine and subaerial volcanic edifices. For example, Urgeles et al. (1997) estimate that in total the debris avalanches on the flanks of El Hierro removed $13 \%$ of the edifice. The north-west facing El Golfo debris avalanche itself removed a quarter of the subaerial El Hierro.

\section{Age of the landslides}

The age of the different landslide events can be estimated from the age of the well-dated onshore rocks on La Palma (Ancochea et al., 1994; Guillou et al., 1997) and El Hierro (Guillou et al., 1996). The lavas and other deposits fossilising the scars provide a minimum age for the landslides, whereas the rocks that have been bisected by the landslide headwalls provide a maximum age estimate (Fig. 5). Radiometric dating of the volcanic rocks associated with the El Golfo debris avalanche has provided a controversial (see Masson, 1996) age range of 136$21 \mathrm{ka}$ (Guillou et al., 1996). On La Palma, the Cumbre Nueva debris avalanche is inferred from radiometric data to have occurred between 536 and 125 ka ago (Guillou et al., 1997). One of the landslides that forms part of the Playa de la Veta debris avalanche complex would have occurred, according to paleomagnetic data, between $1 \mathrm{Ma}$ and $800 \mathrm{ka}$ ago (J.C. Carracedo and S. Day, pers. comm., 1998). The major Canarian debris avalanches (Fig. 5) quoted in several references (Holcomb and Searle, 1991; Fúster et al., 1993; Ancochea et al., 1994; Watts and Masson, 1995, 1998; Masson, 1996; Urgeles et al., 1997, 1999b; Funck and Schmincke, 1998) suggest that the landslide frequency during the last million years has involved one major event every $90 \mathrm{ka}$ for the entire Canary archipelago.

\section{Landslide deposits and rise sedimentation}

Seismic reflection profiles (Urgeles et al., 1998) indicate that the base-of-slope sectors adjacent to the island flanks are largely filled with products derived from mass-wasting processes. These profiles located at the western tip of the volcanic ridge show three main seismic units (Urgeles et al., 1998). From bottom to top these are: 1 , a unit constituted mostly by pelagic sediments and turbidites derived from the 


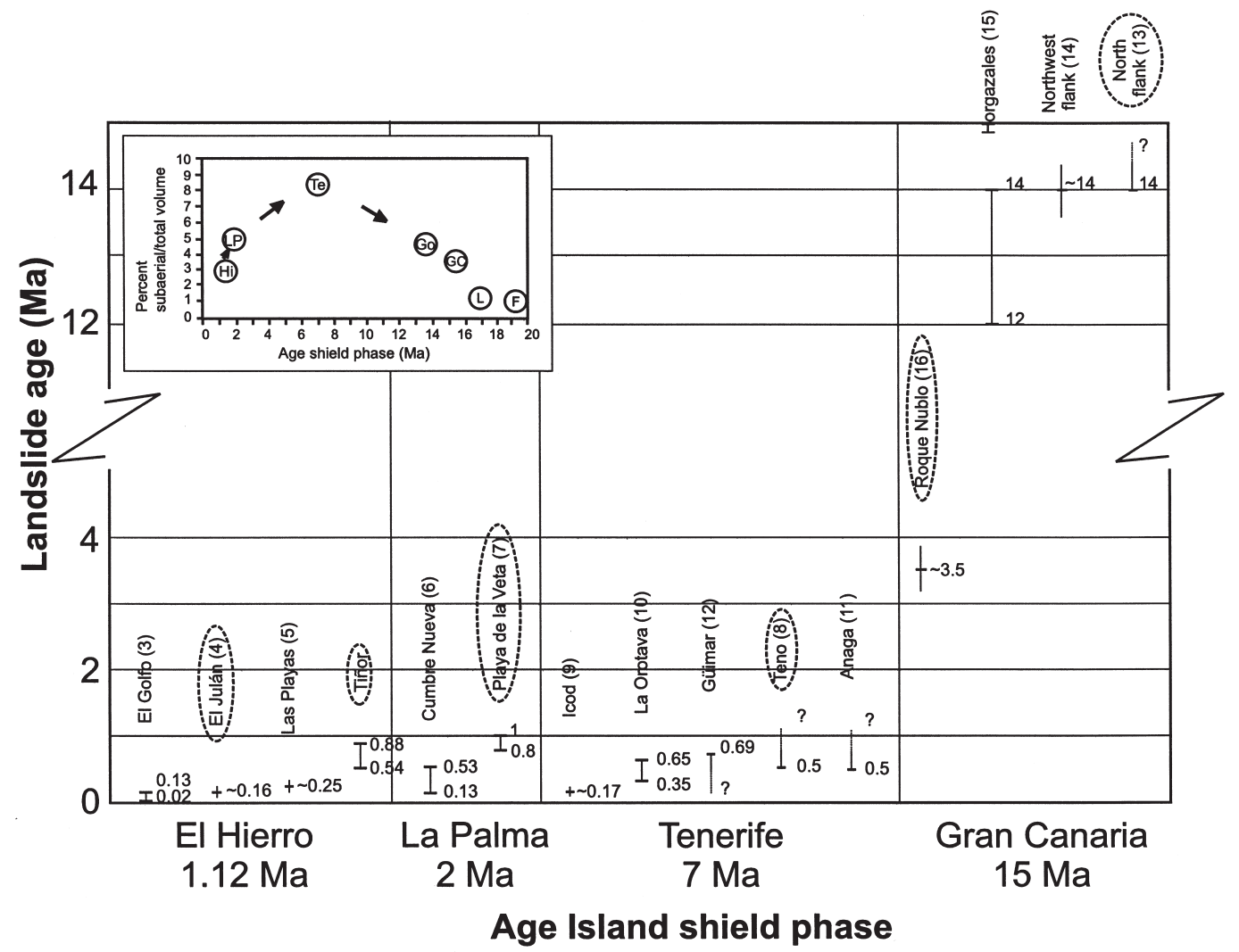

FIG. 5. - Age of debris avalanches for all Canary Islands (Tenerife, La Palma, El Hierro, and Gran Canaria) versus age of the main shield phase. Ages surrounded by dashed ovals are landslides inferred from volcanic stratigraphy of the islands. The insert shows the ratio of subaerial/total volume of the Canary Islands against the age of the main shield phase [modified from Schmincke, 1990]. LP, La Palma; Hi, Hierro; Go, Gomera; Te, Tenerife; GC, Gran Canaria; L, Lanzarote; F, Fuerteventura.

Northwest African margin; 2, a unit with volcaniclastic turbidites superimposed on the background sedimentation constituted by 1 ; and 3 , a third unit with composition similar to 2 but displaying lobular morphologies, which evolves proximally into the large debris avalanche deposits (Fig. 6).

Debris avalanches are the main process driving the volcanic material from the island flanks to the adjacent rise and finally to the MAP. However, minor landslides involving volcanic material also take place on the islands' flanks. Transformation of both minor and large-scale events into debris flows and turbidity currents effectively distributes the sediment throughout the rise and abyssal plain, which is especially evident in units 2 and 3 (Fig. 6). For example, volcaniclastic turbidites derived from the flanks of the Canary Islands are found in the MAP more than 1,000 km from source (Pearce and Jarvis., 1992; Rothwell et al., 1992; Weaver et al., 1992; Masson, 1996; Alibés et al., 1999).

Nevertheless, the occurrence of the giant debris avalanches on the islands' flanks may control the subsequent sediment transport pathways and distribution patterns. Urgeles et al. (1999b) observe that the failed areas of the western flanks of La Palma have developed a network of characteristic flat-bottom, low axial slope gradient, 2-2.5 km wide channels. These channels parallel the boundaries of the depositional lobes formed by successive debris avalanches. As interpreted from backscatter data, these channels trap the coarser sediment fraction of episodic gravity flows that occurred after the main avalanche events, whereas the finer material is washed down (Urgeles et al., 1999b). In contrast, the flanks not affected by the giant failures have narrower and steeper channels without a distinct high backscatter, which allows us to infer that both the coarse and fine sediment fractions are transported mixed to deeper areas.

\section{Triggering mechanisms}

Several studies relate the volcanic rifts (generally evident as prominent ridges) to the lateral collapse of large volcano sectors (Siebert, 1984; Carracedo, 1994; Moore et al., 1989, 1994; Urgeles et al., 1997). Voight and Elsworth (1997) have pointed 

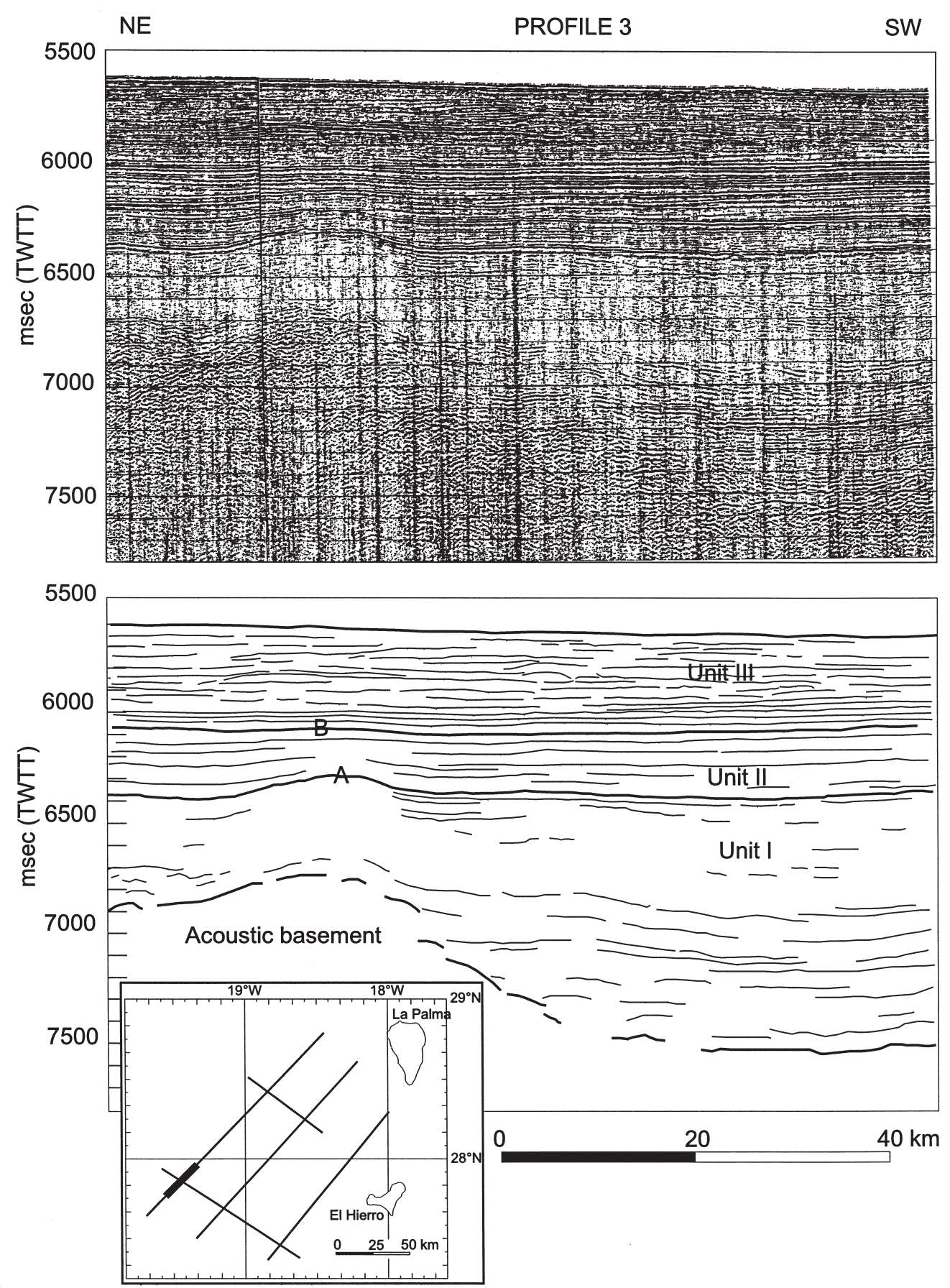

FIG. 6. - Section of seismic reflection profile illustrating the different acoustic facies and units observed west of El Hierro and La Palma. Note unit I onlapping the basement, unit II with very high amplitudes and very continuous reflectors, and unit III with lobes. Location is shown on inset map.

out that dyke intrusion parallel to the ridge axis can significantly contribute to the configuration of the stress field on the volcanic edifice. The scar of El Golfo, on El Hierro, as well as the Cumbre Nueva landslide scar, on La Palma, are oriented normal to the axes of the ridges, which reinforces the idea that dyke intrusion along the ridges has played a fundamental role in landslide initiation.
It should also be recognised, however, that additional mechanisms capable of reducing the shear resistance along the basal plane are needed for the large debris avalanches to occur (Elsworth and Voight, 1995; Voight and Elsworth, 1997). Otherwise, it would have been highly unlikely that landslides the size of El Golfo or Cumbre Nueva would take place. One of the potential mechanisms that has 


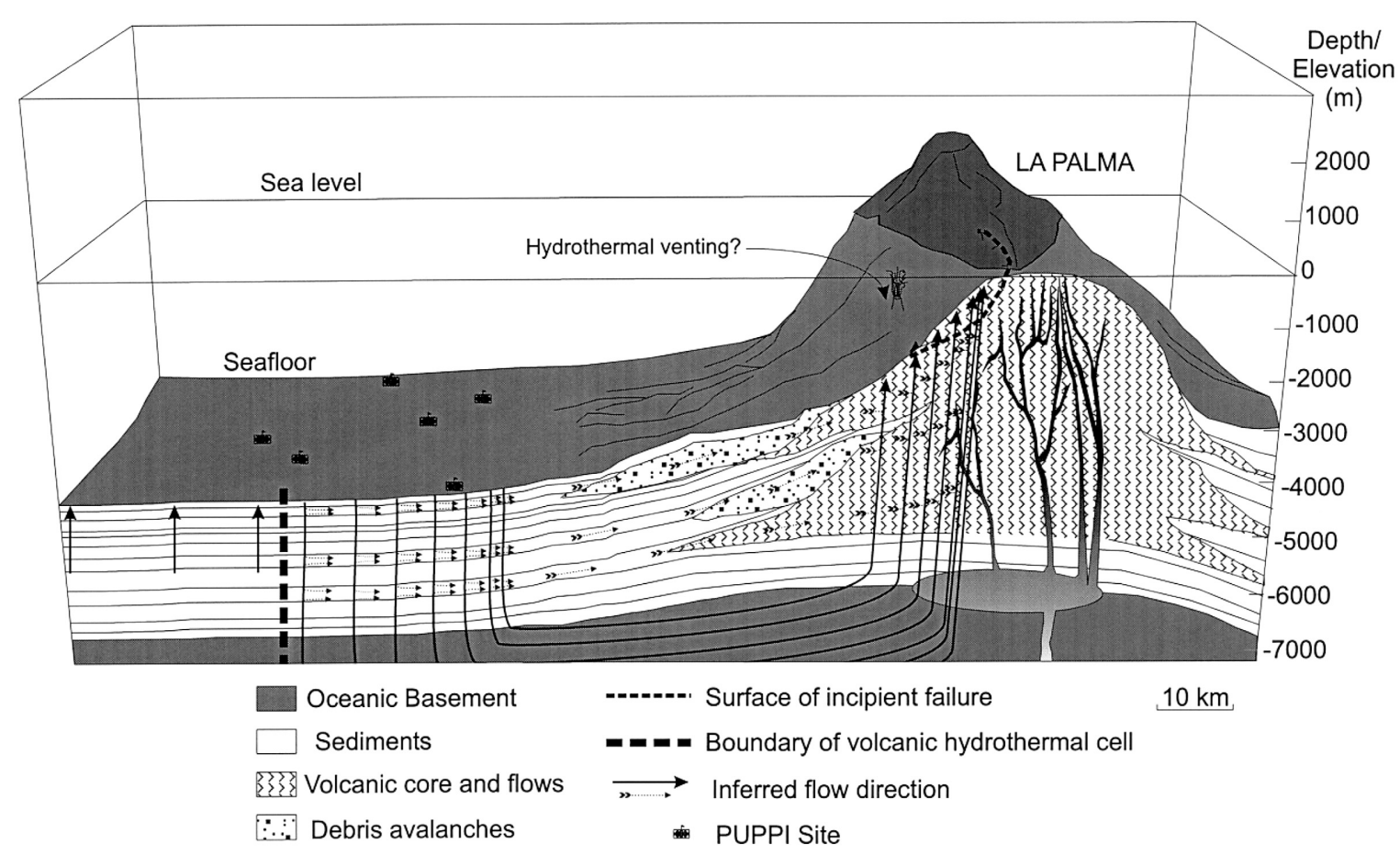

FIG. 7. - Model of fluid flow path on the flanks of an oceanic island as shown by the distribution of ambient pore pressures recorded by the PUPPI apparatus. Depth of shallow magma chambers as inferred from Kluegel et al. (1997), with uplifted basement inferred from Urgeles et al. (1998).

been investigated is excess pore pressure (Urgeles et al., 1999a). Data recorded with PUPPI apparatus on the sediments of the rise west of La Palma provide evidence of pore pressures and fluid circulation which can be interpreted to result from hydrothermal circulation. Estimated ambient pore pressures mostly show negative values (between -10 and -70 Pa) (Fig. 7 ), which would indicate a downward fluid flow in the range of 0 to $-0.3 \mathrm{~mm} \mathrm{y}^{-1}$, given the low permeabilities and high compressibilities of these sediments. The ambient pore pressure distribution on the sediments indicates a complex fluid circulation pattern through the sediment layer. Nevertheles, a prevailing downward fluid flow is observed, which favours the stability of the sediments there. However, as a result of hydrothermal circulation, excess pore pressures can be induced on the most proximal island flanks, where fluid flow is hypothesised to occur upwards, therefore reducing shear resistance.

\section{ACKNOWLEDGEMENTS}

This work was supported by the European Union MAST-II Programme, project MAS2-CT94-0083 (STEAM); the projects MAR98-0347 (GRANDES) and AMB94-0323 (CRESCENT) funded by the Spanish National Agency for Science and Technol- ogy (CICYT); and the "Comissionat per a Universitats i Recerca" (CUR) of the "Generalitat de Catalunya," project 1997SGR-80. R. Urgeles held a fellowship of the CUR. I. Alonso and an anonymous reviewer provided constuctive suggestions, which helped improving the manuscript and are greatly appreciated.

\section{REFERENCES}

Alibés, B., R.G. Rothwell, M. Canals, P.P.E. Weaver and B. Alonso. - 1999. Determination of sediment volumes, accumulation rates and turbidite emplacement frequencies on the Madeira Abyssal Plain (NE Atlantic): a correlation between seismic and borehole data. Mar. Geol., 160: 225-250.

Ancochea, E., E. Hernán, A. Cendrero, J.M. Cantagrel, J.M. Fúster, E. Ibarrola and J. Coello. - 1994. Constructive and destructive episodes in the building of a young oceanic island, La Palma, Canary Islands, and the genesis of the Caldera de Taburiente. $J$. Volcanol. Geotherm. Res., 60: 243-262.

Bravo, T. - 1962. El circo de las Cañadas y sus dependencias. Boletín de la Real Sociedad Española de Historia Natural, 60: 93-108.

Bravo, T. - 1982. Formaciones geológicas de la isla de El Hierro, Instituto de Estudios Canarios, pp. 83-99, La Laguna (Tenerife), Spain.

Canales, J.P. and J.J. Dañobeitia. - 1998. The Canary Islands swell: a coherence analysis of bathymetry and gravity. Geophys. J. Int., 132: 479-488.

Carracedo, J.C. - 1994. The Canary Islands: An example of structural control on the growth of large oceanic-islands volcanoes. J. Volcanol. Geotherm. Res., 60: 225-241.

Carracedo, J.C., H. Guillou, J. Laj, K. Kissel, J.F. Pérez Torrado and E. Rodríguez Badiola. - 1995. Volcanic history of the island of El Hierro, Canarian Archipelago. EGU 8 Meeting, EGU 8 Meeting, European Geophysical Union, Strasbourg, France, Terra Nova (abstracts supplement), 7: 162. 
Carracedo, J.C., S.J. Day and H. Guillou. - 1999. Giant Quaternary landslides and the evolution of La Palma and El Hierro, Canary Islands. J. Volcanol. Geotherm. Res., 94: 169-190.

Carracedo, J.C., S.J. Day, H. Guillou, E. Rodríguez Badiola, J.A Canas and F.J. Pérez Torrado. - 1998. Hotspot volcanism close to a passive continental margin: the Canary Islands. Geological Magazine, 135: 591-604.

Duin E.J.T., C.S. Mesdag and P.T.J. Kok. - 1984. Faulting in the Madeira Abyssal Plain sediments. Mar. Geol., 56: 299-308.

Elsworth, D. and B. Voight. - 1995. Dike intrusion as a trigger for large earthquakes and the failure of volcano flanks. J. Geophys. Res., 100: 6005-6024.

Flewellen, C.G., N.W. Millard and I.P. Rouse. - 1993. TOBI, a vehicle for deep ocean survey. Electronic and Communication Engineering Journal, 5: 85-93.

Funck, T. and H.-U. Schmincke. - 1998. Growth and destruction of Gran Canaria deduced from seismic reflection and bathymetric data. J. Geophys. Res., 103: 15393-15407.

Fúster, J.M., F. Hernán, A. Cendrero, J. Coello, J.M. Cantagrel, E. Ancochea and E. Ibarrola. - 1993. Geocronología de la isla de El Hierro (Islas Canarias). Boletín de la Real Sociedad Española de Historia Natural, 88: 85-97.

Gee, J., H. Staudigel, L. Tauxe, T. Pick and Y. Gallet. - 1993. Magnetization of the La Palma seamount series: Implications for seamount paleopoles. J. Geophys. Res., 98: 11743-11767.

Guillou H., J.C. Carracedo, F. Pérez Torrado and E. Rodríguez Badiola. - 1996. K-Ar ages and magnetic stratigraphy of a hotspot-induced, fast grown oceanic island: El Hierro, Canary Islands. J. Volcanol. Geotherm. Res., 73: 141-155.

Guillou, H., J.C. Carracedo and S.J. Day. - 1997. Unspiked K-Ar dating rocks from El Hierro and La Palma. Int. Workshop on Immature Oceanic Islands, CSIC., La Palma, Spain.

Hausen, H. - 1961. Canarian calderas. Bulletin de la Commision Géologique de Finlande, 196: 179-213.

Hausen, H. - 1969. Some contributions to the geology of La Palma. Commentationes Physico-Mathematicae, 35: 1-140.

Hausen, H. - 1973. Outlines of the geology of Hierro (Canary Islands). Commentationes Physico-Mathematicae, 43: 65-146.

Holcomb, R.T. and R.C. Searle. - 1991. Large landslides from oceanic volcanoes. Mar. Geotechnol., 10: 19-32, 1991.

Holik, J.S. and P.D. Rabinowitz. - 1991. Effects of Canary hotspot volcanism on structure of oceanic crust off Morocco. J. Geophys. Res., 96: 12039-12067.

Keeton, J.A. and R.C. Searle. - 1996. Analysis of Simrad Em12 multibeam bathymetry and acoustic backscatter data for seafloor mapping, exemplified at the Mid-Atlantic Ridge at 45degrees-N. Mar. Geophys. Res., 18: 663-688.

Kluegel, A., T.H. Hansteen and H.-U. Schmincke. - 1997. Rates of magma ascent and depths of magma reservoir beneath La Palma (Canary Islands). Int. Workshop on Immature Oceanic Islands, CSIC., La Palma, Spain.

Lenat, J-F., P. Vincent and P. Bachelery. - 1989. The offshore continuation of an active basaltic volcano: Piton de la Fournaise (Réunion Island, Indian Ocean). J. Volcanol. Geotherm. Res. 36: $1-36$

Masson, D.G. - 1996. Catastrophic collapse of the volcanic island of Hierro 15 ka ago. Geology, 24: 231-234.

Masson, D.G., M. Canals, B. Alonso, R. Urgeles, and V. Hühnerbach. - 1998. The Canary Debris Flow: source area, morphology and failure mechanisms. Sedimentology, 45: 411-432.

Masson, D.G., R.B. Kidd, J.V. Gardner, Q.J. Hugget and P.P.E. Weaver. - 1992. Saharan continental rise: Facies distribution and sediment slides. In: C.W. Poag and P.C. de Graciansky (eds.), Geologic Evolution of Atlantic Continental Rises, pp. 327-343. Van Nostrand Reinhold, New York.

Mezcúa, J., E. Buforn, A. Udías and J. Rueda. - 1991. Seismotectonics of the Canary Islands. Tectonophysics, 208: 447-452.

Moore, J.G., D.A. Clague, R.T. Holcomb, P.W. Lipman, W.R. Normark and M.E. Torressan. - 1989. Prodigious submarine landslides on the Hawaiian Ridge. J. Geophys. Res., 94: $14465-14484$

Moore, J.G., W.R. Normark and R.T. Holcomb. - 1994. Giant Hawaiian Landslides. Аnпи. Rev. Earth Planet. Sci., 22: 119-144.

Moore, J.G., W.B. Bryan, M.H. Beeson and W.R. Normark. - 1995 Giant blocks in the South Kona landslide, Hawaii. Geology, 23: $125-128$

Navarro, J.M. and J. Coello. - 1989. Depressions originated by landslide processes in Tenerife. ESF meeting on Canarian Volcan- ism, European Science Foundation, Arrecife, Canary Islands.

Navarro, J.M. and J. Coello. - 1993. Sucesión de episodios en la evolución geológica de La Palma. Mapa geológico de La Palma, ICONA, Madrid.

ODP Leg 157 Shipboard Scientific Party. - 1995. Gran Canaria volcanic apron and Madeira Abyssal Plain drilled. EOS Trans. $A G U, 76:$ 393-395.

Pearce, T.J. and I. Jarvis. - 1992. Composition and provenance of turbidite sands: Late Quaternary, Madeira Abyssal Plain. Mar. Geol., 109: 21-51.

Ranero, C.R., M. Torne and E. Banda. - 1995. Gravity and multichannel seismic reflection constraints on the lithospheric structure of the Canary Swell. Mar. Geophys. Res., 17: 519-534.

Rhim, R., C.L. Jacobs, S. Krastel, H.-U. Schmincke and B. Alibés. - 1998. Las Hijas Seamounts, the next Canary Islands ?. Terra Nova, 10: 121-125.

Ridley, W.I. - 1971. The origin of some collapse structures in the Canary Islands. Geological Magazine, 108: 447-484.

Roeser, H.A., K. Hinz and S. Plaumann. - 1971. Continental margin structure in the Canaries. Institute of Geological Sciences Annual Report, 70/16: 27-36.

Rothe, P. and H.-U. Schmincke. - 1968. Contrasting origins of the eastern and western islands of the Canarian Archipelago. Nature, 218: 1152-1154.

Rothwell, R.G., T.J. Pearce and P.P.E. Weaver. - 1992. Late Quaternary evolution of the Madeira Abyssal Plain, Canary Basin, NE Atlantic. Basin Res., 4: 103-131.

Schmincke, H.-U. - 1990. Geology and geological field guide of Gran Canaria. Pluto Press, Kiel, Germany, 212 pp.

Schultheiss, P.J. - 1989. Pore pressures in marine sediments: An overview of measurement techniques and some geological and engineering applications. Mar. Geophys. Res., 12: 153-168.

Searle, R.C. - 1987. Regional setting and geophysical characterization of the Great Meteor East area in the Madeira Abyssal Plain. In: P.P.E. Weaver and J. Thomson (eds.), Geology and Geochemistry of Abyssal Plains, pp. 49-70, Geological Society Special Publication 31, London.

Siebert, L. - 1984. Large volcanic debris avalanches: characteristics of source areas, deposits, and associated eruptions. J. Volcanol. Geotherm. Res., 22: 163-197.

Urgeles, R., M. Canals, J. Baraza and B. Alonso. - 1998. Seismostratigraphy of the western flanks of Hierro and La Palma (Canary Islands): A record of the Canary volcanism. Mar. Geol., 146: 225-241.

Urgeles, R., M. Canals, J. Baraza, B. Alonso and D.G. Masson. 1997. The last major megalandslides in the Canary Islands: The El Golfo debris avalanche and the Canary debris flow, west Hierro Island. J. Geophys. Res., 102: 20305-20323.

Urgeles, R., M. Canals, J. Roberts and SNV "Las Palmas" Shipboard Party. - 1999a. Fluid flow from pore pressure measurements off La Palma, Canary Islands. J. Volcanol. Geotherm. Res., 94: 305-321.

Urgeles, R., D.G. Masson, M. Canals, A. B. Watts and T. Le Bas. 1999b. Recurrent giant landslides on the west flank of $\mathrm{La}$ Palma, Canary Islands. J. Geophys. Res., 104: 25331-25348.

Voight, B. and D. Elsworth. - 1997. Failure of vocano slopes. Géotechnique, 47: 1-31.

von Rad, U., W.B.F. Ryan, M.A. Arthur, P. Cepek, M.B. Cita, C. Cornford, L. Garifal, N. Hamilton, B. Lopatin, G.F. Lutze, F.W. McCoy, G. Mountain, M. Sarnthein, O.E. Wesser, J.K. Whelan, F.H. Wind, F.H. Laughter and E.M. Fagerberg. 1979. Site 397. In: Initial Reports of the Deep Sea Drilling Project, 47 (1): 17-217.

Watts, A.B. - 1994. Crustal structure, gravity anomalies and flexure of the lithosphere in the vicinity of the Canary Islands. Geophys. J. Int., 119: 648-666.

Watts, A.B. and D.G. Masson. - 1995. A Giant landslide on the north flank of Tenerife, Canary Islands. J. Geophys. Res., 100: $24487-24498$

Watts, A.B., and D.G. Masson. - 1998. Reply. J. Geophys. Res., 103: 9949-9952.

Weaver, P.P.E., R.G. Rothwell, J. Ebbing, D. Gunn and P.M. Hunter. - 1992. Correlation, frequency of emplacement and source directions of megaturbidites on the Madeira Abyssal Plain. Mar. Geol., 109: 1-20.

Wijbrans, J., L.Tauxe and H. Staudigel. - 1997. Eruptive chronology of the Taburiente Volcano, La Palma. Int. Workshop on Immature Oceanic Islands, CSIC, La Palma, Spain. 
